\title{
Polyoxin D Inhibits Colloidal Gold-Wheat Germ Agglutinin Labelling of Chitin in Dimorphic Forms of Candida albicans
}

\author{
By L. L. HILENSKI, ${ }^{1}$ F. NAIDER ${ }^{2}$ AND J. M. BECKER ${ }^{1 *}$ \\ ${ }^{1}$ Department of Microbiology, The University of Tennessee, Knoxville, \\ Tennessee 37996-0845, USA \\ ${ }^{2}$ Department of Chemistry, College of Staten Island, Staten Island, New York 10301, USA
}

(Received 26 November 1985 ; revised 31 January 1986)

\begin{abstract}
Yeasts and mycelia of the pathogen Candida albicans grown in the presence of polyoxin D, a competitive inhibitor of chitin synthase, formed chains of swollen bulbous cells as observed by fluorescence microscopy. Wheat germ agglutinin (WGA) complexed to colloidal gold ( $\mathrm{Au}$ ) was used as a specific label at the ultrastructural level to visualize chitin in walls of control and polyoxin-treated cells. In control cells, Au-WGA labelling was preferentially localized in the innermost wall layers and was predominant at bud scars and septa. After $4.5 \mathrm{~h}$ in $4 \mathrm{~mm}$-polyoxin $\mathrm{D}$, budding in yeasts and lateral wall growth in mycelia continued, but primary septa failed to form and no $\mathrm{Au}$-WGA labelling was detected in the walls. These results demonstrated that the morphological alterations caused by polyoxin $\mathrm{D}$ were due to the absence of chitin, a wall component important for formation of primary septa and for maintenance of structural integrity during morphogenesis.
\end{abstract}

\section{INTRODUCTION}

Secondary fungal infections associated with immunocompromising diseases and/or immunosuppressing medications present an increasing medical problem because most currently used antifungal drugs have toxic side-effects on the host (Meunier-Carpentier et al., 1981; Bodey \& Fainstein, 1985). One approach to antifungal chemotherapy has been to exploit the fact that chitin, a characteristic component of fungal cell walls (Bacon, 1981), is not found in human tissues (Muzzarelli, 1977); thus inhibitors of chitin synthesis and/or assembly should be specific and affect only fungal cell growth. Polyoxins (Isono et al., 1967) are excellent candidates for antifungal drugs because they inhibit chitin synthesis (Endo et al., 1970; Ohta et al., 1970). Polyoxin D, a strong competitive inhibitor of chitin synthase owing to its structural similarity to UDP- $N$-acetylglucosamine (Hori et al., 1971), has been shown to inhibit growth of Candida albicans (Becker et al., 1983), one of the most prevalent of the opportunistic pathogens. This report also described the effects of polyoxin D on the growth and morphology of Candida (Becker et al., 1983), using light microscopy. In the presence of the antibiotic, budding yeasts did not form septa but instead formed chains of swollen, osmotically sensitive cells. This altered morphology was interpreted as the result of inhibition of chitin incorporation into growing cell walls, thus weakening the walls and making them susceptible to lysis.

Here we extend these observations to the ultrastructural level by labelling chitin with wheat germ agglutinin complexed to colloidal gold. Our aims were to (1) visualize the location of chitin in dimorphic forms of $C$. albicans and (2) determine what effect polyoxin D has on the distribution of chitin in the cell walls.

Abbreviation: WGA, wheat germ agglutinin. 


\section{METHODS}

Organism and cell culture. Candida albicans H317 was a clinical isolate obtained from the Centers for Disease Control, Atlanta, Ga. Stock cultures were maintained on Sabouraud dextrose agar (BBL Division of Becton, Dickinson \& Co.) at $4^{\circ} \mathrm{C}$ and transferred monthly.

Yeast cells from Sabouraud agar slants were inoculated into $100 \mathrm{ml}$ of an amino acid synthetic medium (Lee $e t$ al., 1975) at pH 4.5 and were grown in $500 \mathrm{ml}$ flasks at $37^{\circ} \mathrm{C}$ on a reciprocating shaker for $22 \mathrm{~h}$. Samples were then diluted 1:40 with fresh Lee's medium, $\mathrm{pH} 4 \cdot 5$, and further incubated for $20 \mathrm{~h}$ as above. When these cultures reached stationary phase at a concentration of $1 \times 10^{8}$ cells ml-1, $25 \mathrm{ml}$ samples were centrifuged, and the cells were washed in Lee's medium, $\mathrm{pH} 4 \cdot 5$, and resuspended in $25 \mathrm{ml}$ fresh medium. This latter culture served as the inoculum for experimental procedures.

Polyoxin D treatment. Polyoxin D was purified from a preparation supplied by Kaken Chemical (Honkomagome, Tokyo, Japan) as described previously (Shenbagamurthi et al., 1982). Parallel cultures from the inoculum were diluted 1:20 in Lee's medium at $\mathrm{pH} 4.5$ for maintenance of yeast growth and at $\mathrm{pH} 6.8$ for induction of mycelia (Mitchell \& Soll, 1979), and were initially incubated at $37^{\circ} \mathrm{C}$ on a reciprocating shaker for $3.5 \mathrm{~h}$. After this initial culture period, samples grown at $\mathrm{pH} 4.5$, containing $8 \times 10^{6} \mathrm{cells} \mathrm{ml}^{-1}$ with $88 \%$ budding cells, were then centrifuged and the cells were resuspended in Lee's medium at $\mathrm{pH} 4.5$ with or without 4 mM-polyoxin $\mathrm{D}$. Cultures grown at $\mathrm{pH} 6.8$, containing $8 \times 10^{6}$ cells $\mathrm{ml}^{-1}$ with $60 \%$ germ tubes, were centrifuged and resuspended in Lee's medium at $\mathrm{pH} 6.8$ with or without $4 \mathrm{~mm}$-polyoxin $\mathrm{D}$. Control and drug-treated cultures were further incubated for $4.5 \mathrm{~h}$ or $24 \mathrm{~h}$ at $37^{\circ} \mathrm{C}$ as above and then processed for fluorescence light microscopy; cultures grown for $4.5 \mathrm{~h}$ were processed for transmission electron microscopy.

Fluorescence microscopy. Cell pellets were resuspended in $200 \mu 10.01 \%(\mathrm{w} / \mathrm{v})$ Calcofluor white M2R

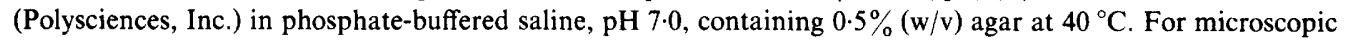
observations, $6 \mu l$ of the suspension was placed between a glass slide and coverslip and allowed to cool. Fluorescence was observed with a Leitz Orthoplan microscope equipped with a xenon-mercury lamp and a Phloem illuminator using an exciting filter BP 340-380, a beam splitting mirror RKP 400 and a suppression filter LP 430. Micrographs were taken on Kodak Tri-X Pan film at exposure times of 4-10 s.

Preparation of colloidal gold-wheat germ agglutinin. Colloidal gold ( $\mathrm{Au}$ ) was prepared according to Frens (1973). Briefly, $3 \mathrm{ml}$ of freshly prepared $1 \%(\mathrm{w} / \mathrm{v})$ sodium citrate, $\mathrm{pH} 8 \cdot 5$, was added to $50 \mathrm{ml}$ deionized water boiling under reflux. After $5 \mathrm{~min}, 0.5 \mathrm{ml}$ of $1 \%(\mathrm{w} / \mathrm{v})$ chloroauric acid (ICN Pharmaceuticals) was added and boiling continued for $15 \mathrm{~min}$. The Au solution was cooled and centrifuged at $12100 \mathrm{~g}$ for $15 \mathrm{~min}$ at $4{ }^{\circ} \mathrm{C}$. The Au particles were $12.84 \pm 1.0 \mathrm{~nm}$ in diameter.

Wheat germ agglutinin (WGA; Pharmacia) complexed to Au was prepared and thin sections of yeasts and mycelia were labelled as described by Roberts et al. (1983). Controls consisted of floating sections on the following solutions: Au without WGA, and Au-WGA in the presence of chitin.

Transmission electron microscopy. Yeasts and mycelia were processed by the method of Arnold as cited by Garrison (1981). Cell pellets incorporated into $2 \%(\mathrm{w} / \mathrm{v})$ agar at $40{ }^{\circ} \mathrm{C}$ were solidified and cut into $1 \mathrm{~mm}^{3}$ blocks. Cells in the blocks were exposed to $5 \%(\mathrm{w} / \mathrm{v})$ potassium permanganate for 2 min, dehydrated quickly in $25 \%$ and $50 \%(\mathrm{v} / \mathrm{v})$ ethanol and then through an alcohol series. The blocks were embedded in Spurr's medium (Spurr, 1969) and sectioned with a Diatome diamond knife on a Reichert Ultramicrotome Om U3. Thin sections except where stated were poststained with methanolic uranyl acetate and lead citrate and were examined with either a Zeiss EM $9 \mathrm{~S}-2$ operated at $50 \mathrm{kV}$ or a Hitachi $\mathrm{H}-600$ operated at $75 \mathrm{kV}$.

As a control for $\mathrm{Au}-\mathrm{WGA}$ labelling, yeast cells fixed in the G-O-T-O-U (glutaraldehyde, osmium, tannic acid, osmium, uranyl acetate) procedure (Persi \& Burnham, 1981) were sectioned, labelled with Au-WGA, and examined as stated above.

\section{RESULTS}

\section{Fluorescence light microscopy}

Yeast phase. Morphological effects of polyoxin D on yeast cells and mycelia were readily seen by staining the cell wall with Calcofluor white $\mathrm{M} 2 \mathrm{R}$, a fluorescent brightener that binds to $\beta$ linked glucans and chitin (Maeda \& Ishida, 1967; Hayashibe \& Katohda, 1973). Cells cultured in Lee's medium, $\mathrm{pH} 4.5$, at $37^{\circ} \mathrm{C}$ for $4.5 \mathrm{~h}$ were maintained in the yeast phase and formed ellipsoidal buds. Yeast cell walls were faintly fluorescent while the narrow constriction corresponding to the septum between the mother cell and bud exhibited intense fluoresence (Fig. 1 a). Although polyoxin D did not inhibit bud formation, the mother-bud junction in drugtreated cells was wider and less fluorescent (Fig. 1b) than in control cells. After $24 \mathrm{~h}$ in the antibiotic, yeasts formed chains of weakly fluorescent cells, which remained attached to the more intensely fluorescent mother cell (Fig. 1c). 

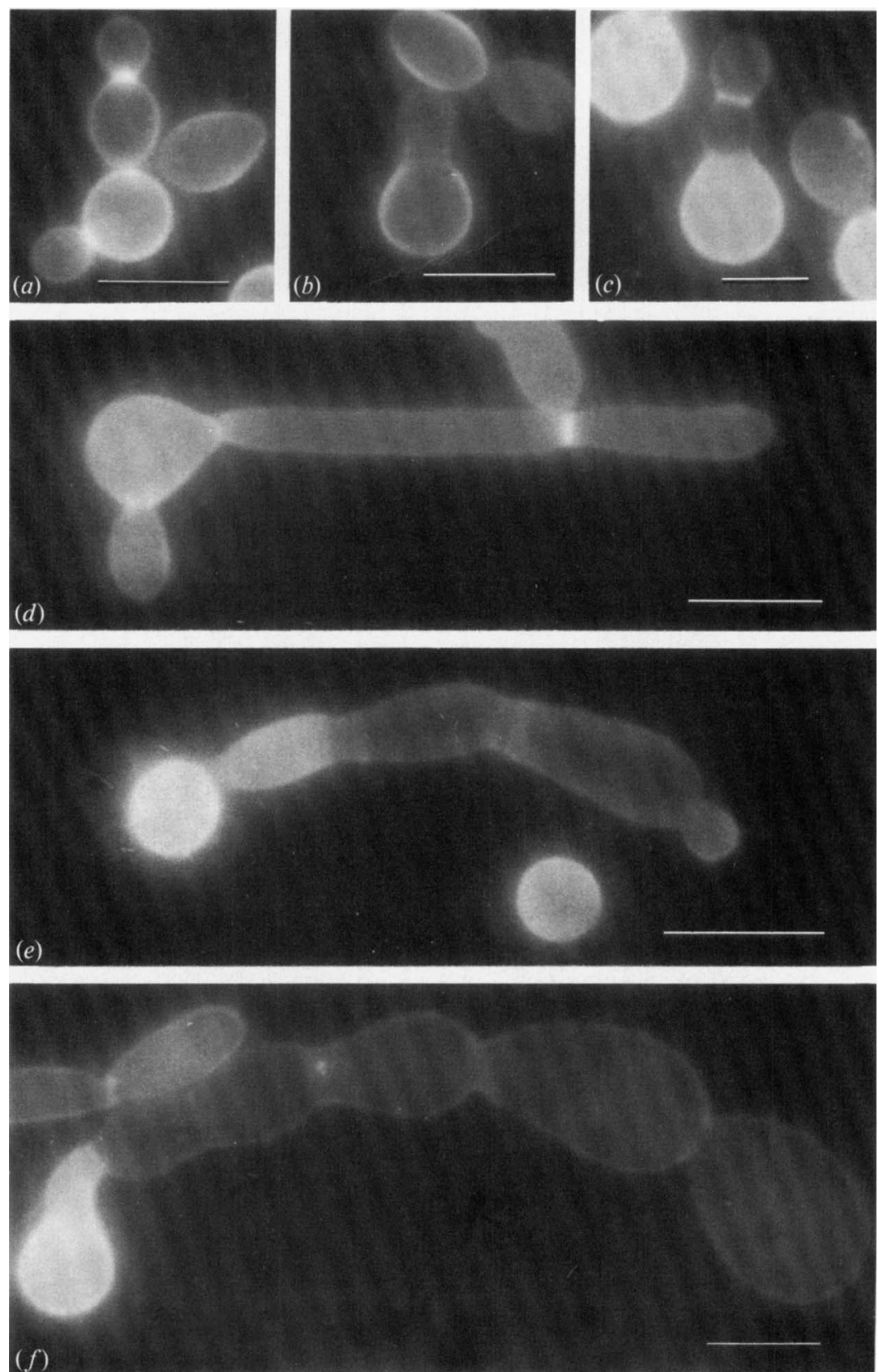

Fig. 1. Fluorescence photomicrographs illustrating morphological effects of polyoxin $\mathrm{D}$ on $C$. albicans yeast and mycelia stained with Calcofluor white. $(a-c)$ Yeast phase grown in Lee's medium at pH 4.5. (a) Control culture with budding cells showing intense fluorescence at septum. (b) Septum no longer apparent in budding cells after $4.5 \mathrm{~h}$ in polyoxin D. (c) Chain of unseparated buds attached to mother cell after $24 \mathrm{~h}$ in polyoxin D. $(d-f)$ Mycelial phase grown in Lee's medium at pH 6.8. $(d)$ Control cell with bright fluorescent septum along cylindrical tube. (e) Hyphal tube after $4.5 \mathrm{~h}$ in polyoxin D with swollen distal sections showing diminished fluorescence. Constrictions are marked by faint fluorescent bands. $(f)$ Chain of bulbous cells along hyphal tube length after $24 \mathrm{~h}$ in polyoxin $\mathrm{D}$. Constrictions at distal end of chain are narrower than those nearest the mother cell. Bars, $10 \mu \mathrm{m}$. 


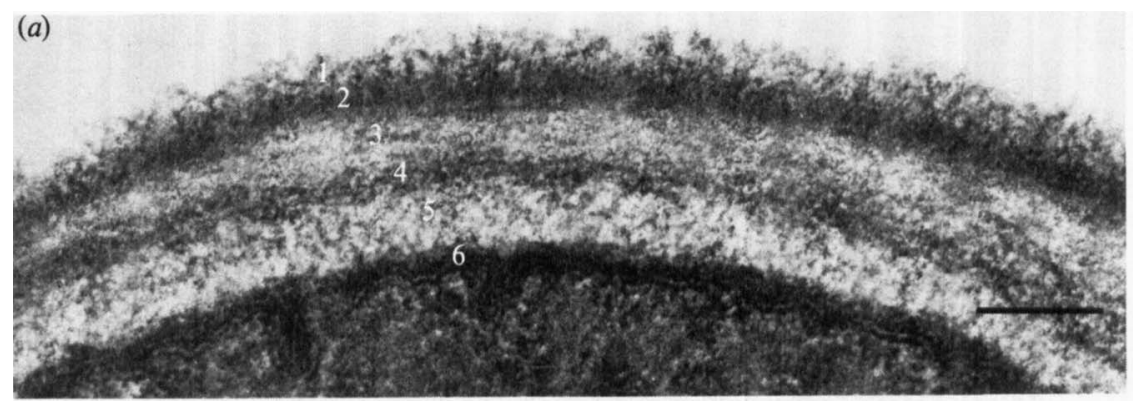

(b)
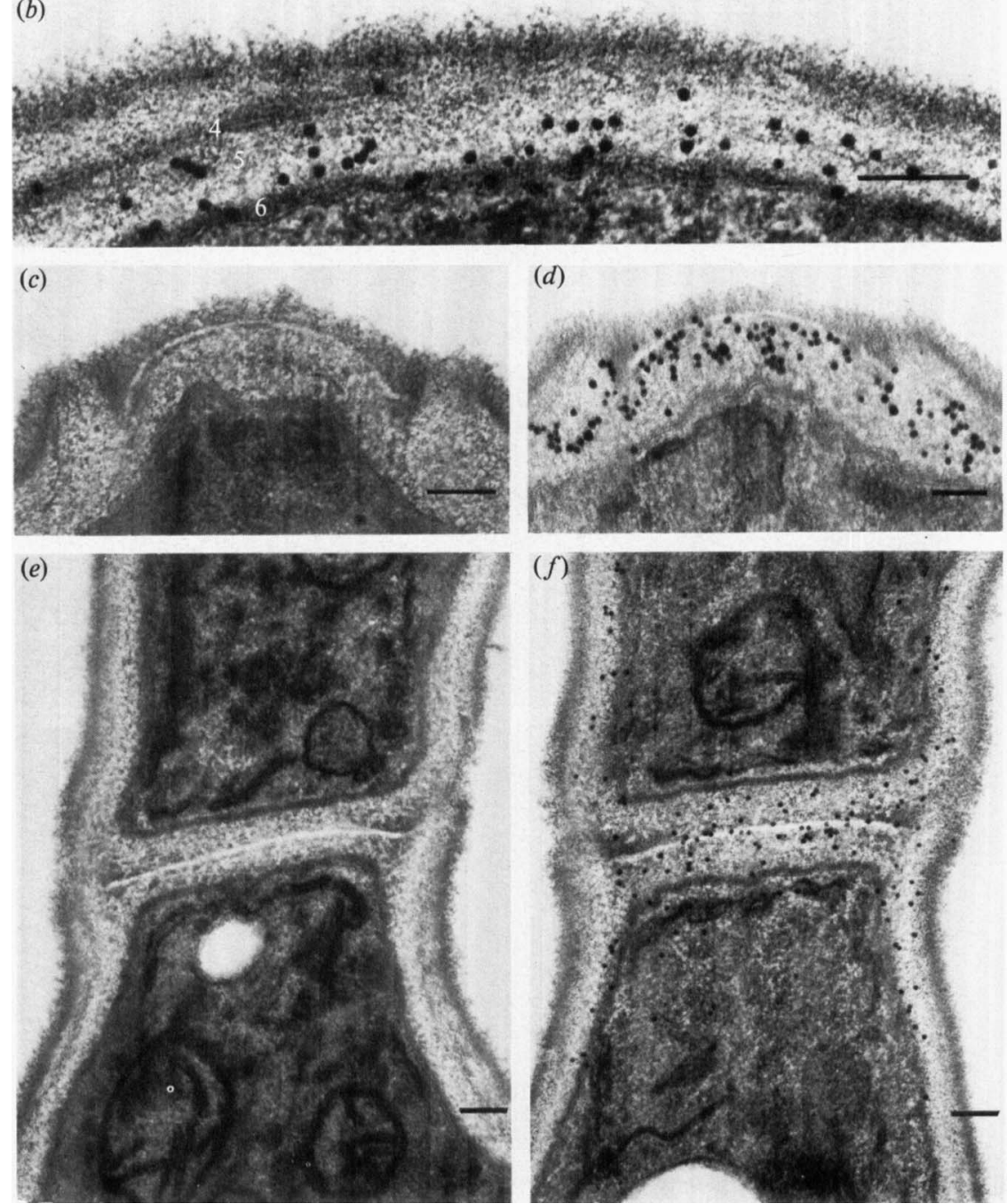

Fig. 2. Au-WGA labelling of wall layers and septa. (a) Control cell wall with six layers of yeast fixed in $\mathrm{KMnO}_{4}$. (b) Au-WGA labelling predominantly found in inner wall layers 4, 5 and 6 . Note discontinuities in layer 4. (c) Bud scar of control yeast cell with characteristic electron-transparent primary septum beneath layer 1 . Wall layers 2,3 and 4 are not apparent. (d) Au-WGA labelling is most dense at bud scar and extends to boundary of layer 1. (e) Mycelial cell junction with characteristic trilaminate appearance of electron-transparent primary septum flanked by two secondary septal layers. ( $f$ ) Au-WGA labelling dispersed over primary and secondary septa. Bars, $0.1 \mu \mathrm{m}$. 
(a)

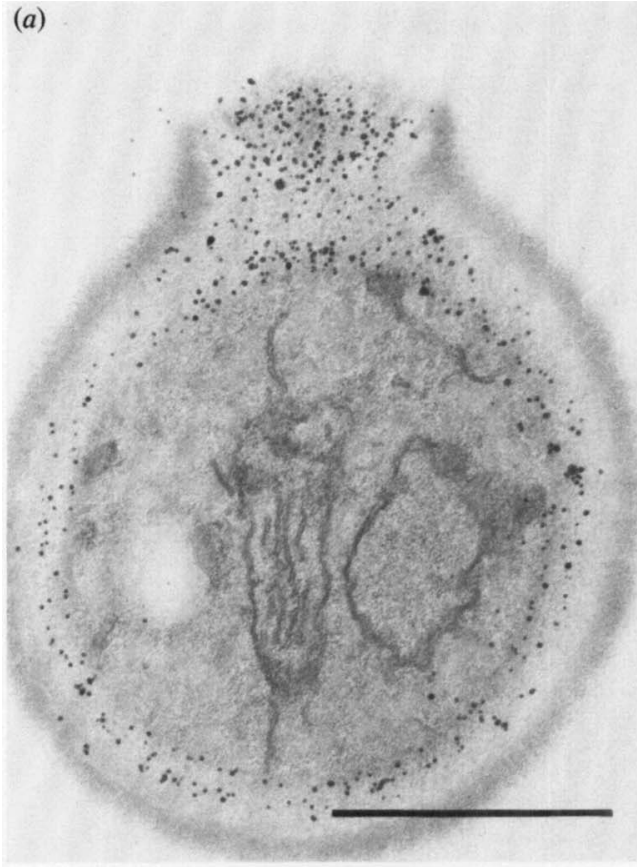

(b)

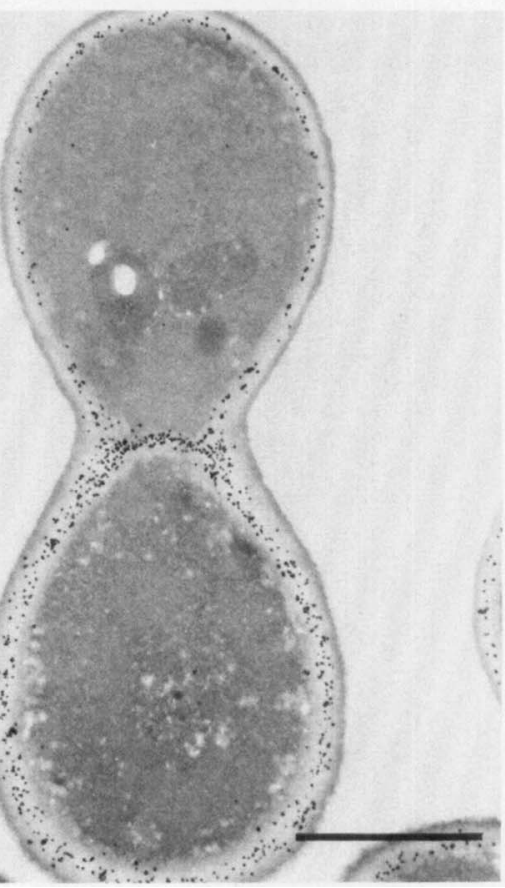

(c)

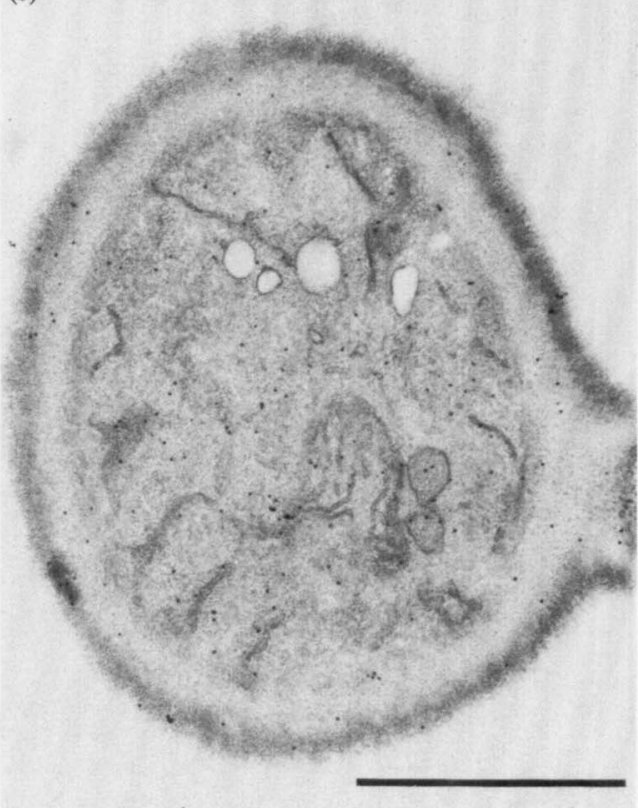

(d)

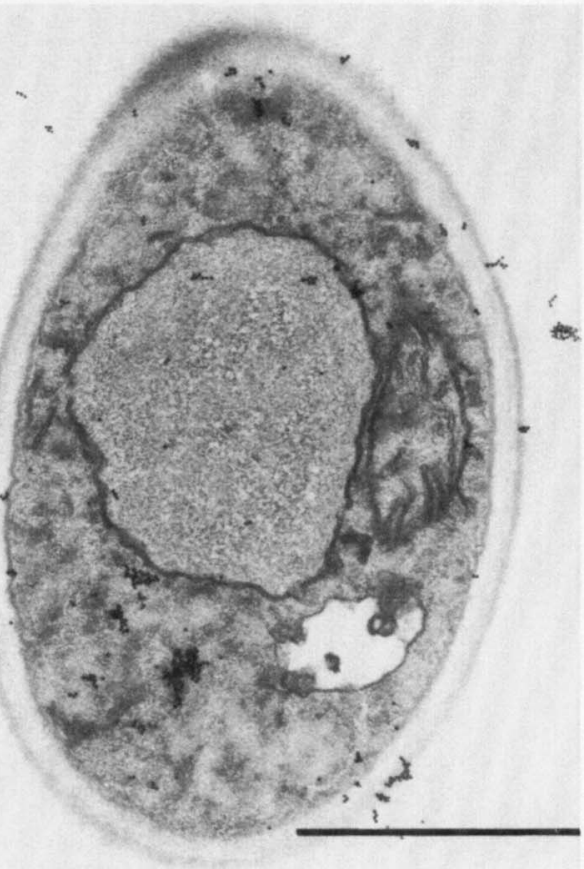

Fig. 3. Labelling controls. (a) Cell fixed in $\mathrm{K} \mathrm{MnO}_{4}$ with labelling confined to cell wall and localized primarily in inner wall layers. Note dense labelling of bud scar. (b) Budding cells fixed in G-O-T-O-U with specific labelling in walls of mother cell and bud. Heaviest labelling in mother cell wall and at septum. Unstained thin section. (c) Au not complexed to WGA exhibited nonspecific labelling over entire cell. $(d) \mathrm{Au}-\mathrm{WGA}$-chitin aggregates in nonspecifically labelled cell. Bars, $1 \mu \mathrm{m}$. 

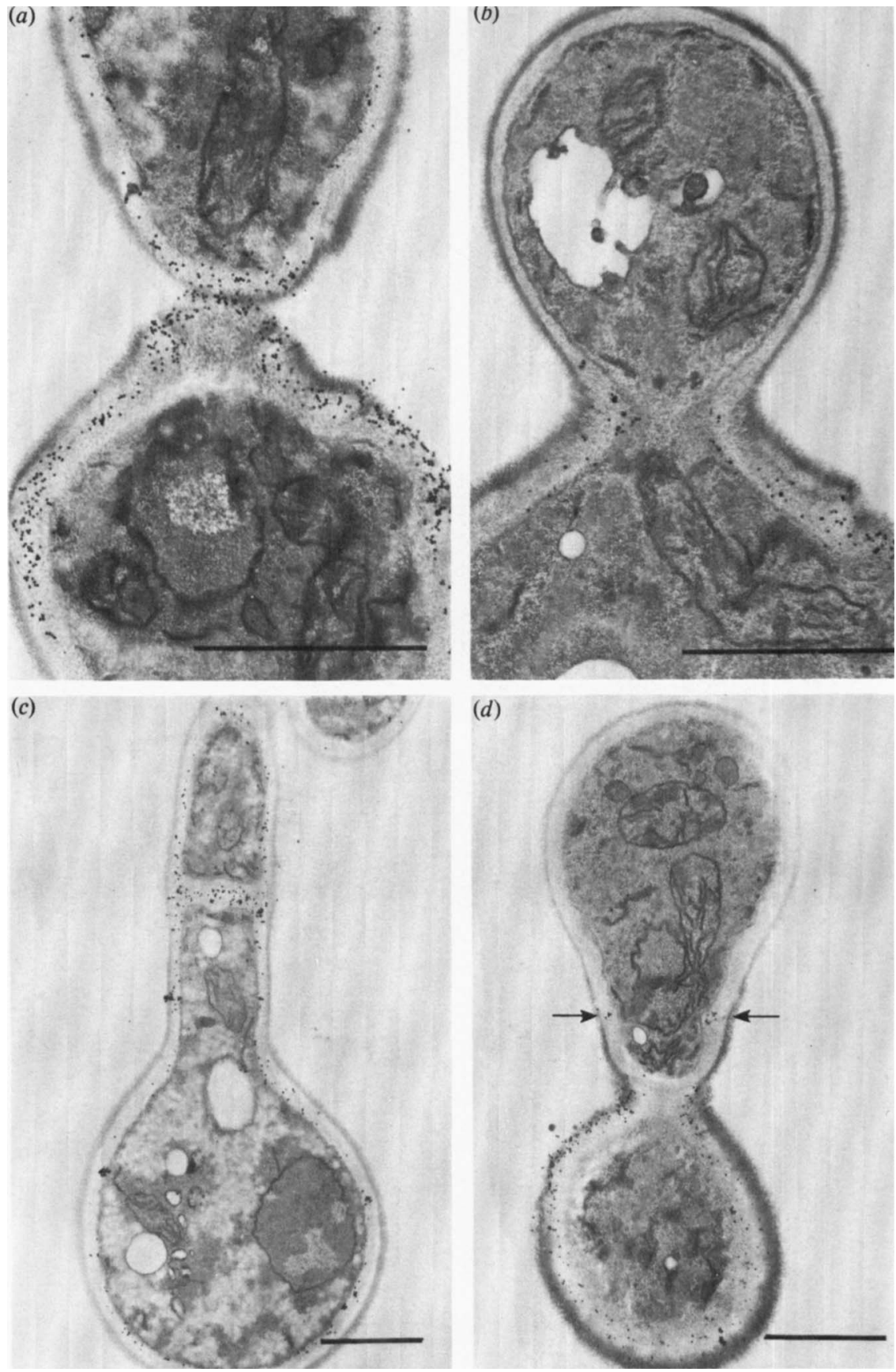

Fig. 4. Effects of $4 \mathrm{~mm}$-polyoxin D on Au-WGA labelling in yeast $(a, b)$ and mycelium $(c, d)$. $(a)$ Control yeast showing Au-WGA labelling in walls of both mother cell and bud. (b) Yeast in presence of $4 \mathrm{~mm}$-polyoxin $\mathrm{D}$ for $4.5 \mathrm{~h}$ with labelling in thick mother cell wall but no labelling in thinner wall of bud. (c) Germ tube of control culture with labelling throughout mother cell wall, septum and germ tube wall. (d) Labelling absent in walls of bulbous germ tube treated with polyoxin D. Note isolated clusters of $\mathrm{Au}-$ WGA particles (arrowed) in proximity to cytoplasmic invaginations $1 \mu \mathrm{m}$ distal from mother cellmycelial junction. Bars, $1 \mu \mathrm{m}$. 

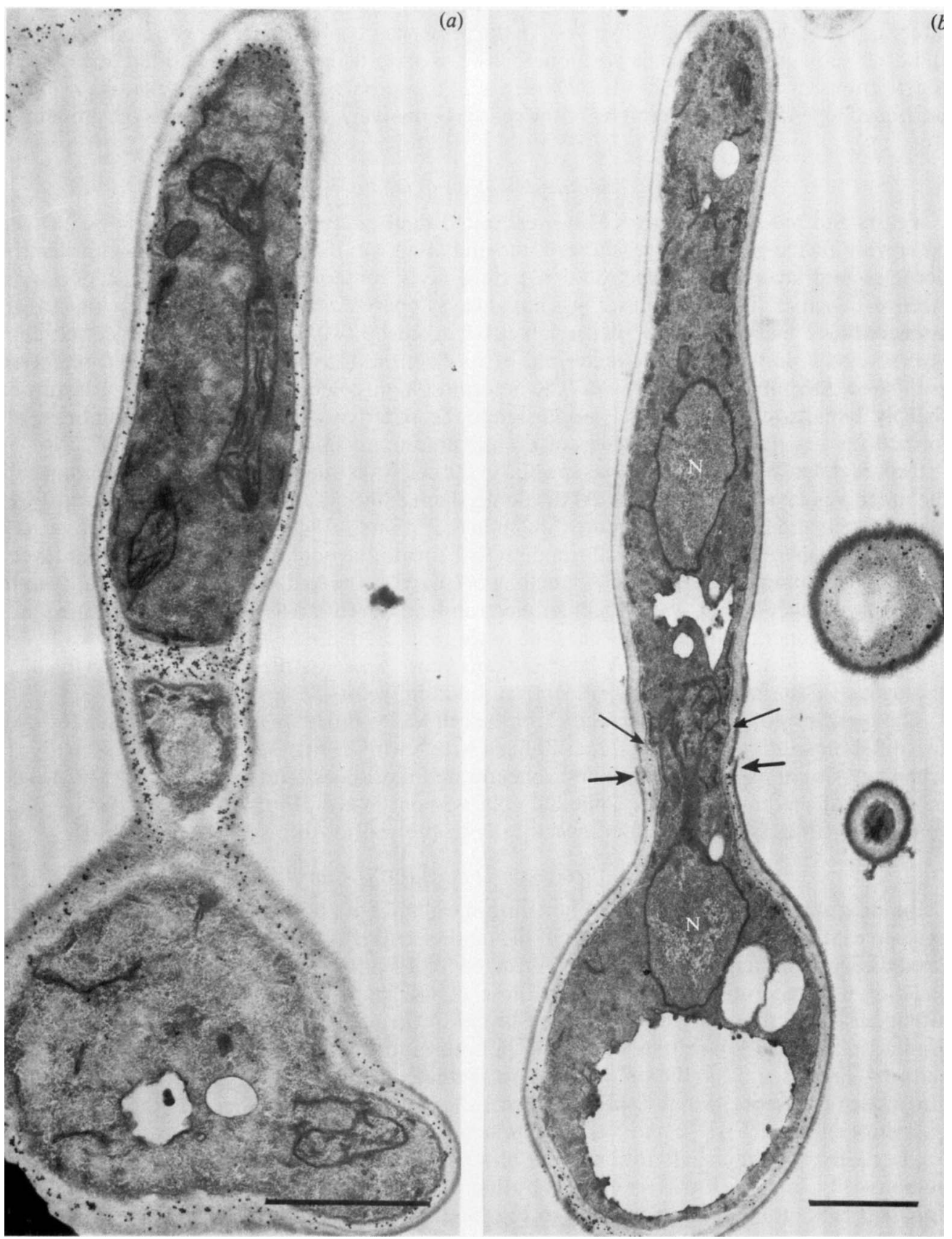

Fig. 5. Comparison of germ tubes without $(a)$ and with $(b) 4 \mathrm{~mm}$-polyoxin D for $4.5 \mathrm{~h}$. In the control cell, heavily labelled septum occurred $1 \mu \mathrm{m}$ distal to mother cell. At a comparable position in the drugtreated cell, labelling of the mother cell wall was terminated, cytoplasm showed evaginations (thin arrows) and wall showed small projections (thick arrows). Note nucleus $(\mathrm{N})$ in both mother cell and tube. Bars, $1 \mu \mathrm{m}$. 
Mycelial phase. When the $\mathrm{pH}$ of the culture medium was shifted to 6.8, cells formed linear, elongated germ tubes of uniform diameter. Brightly fluorescent septa occurred at irregular intervals along the tube length (Fig. $1 d$ ). In the presence of polyoxin $\mathrm{D}$, the germ tubes formed a chain of bulbous, swollen cells with one or two weakly fluorescent bands often appearing at constrictions in the tubes (Fig. $1 e$ ). During a $24 \mathrm{~h}$ exposure to polyoxin $\mathrm{D}$, the chain of cells continued to lengthen, the diameter of the cells progressively increasing towards the growing tip (Fig. $1 f$ ).

\section{Transmission electron microscopy}

Yeasts and mycelia fixed in $\mathrm{KMnO}_{4}$ exhibited thick multilayered cell walls (Fig. 2a). The outermost fibrillo-granular layer merged into and often was indistinguishable from an electrondense second layer. A less electron-dense third layer contained amorphous areas of varying electron densities. The fourth layer was not always apparent or was discontinuous (Fig. $2 b$ ) and appeared as a narrow electron-dense lamella flanked by two thicker and less electron-dense layers 3 and 5 . Layer 5 was characterized by its electron-transparent matrix with interspersed granules of medium electron density. The innermost highly electron-dense layer was narrow but sharply demarcated; it was closely appressed to the underlying tortuous plasma membrane and formed the matrix in the interstices of the membrane invaginations.

Colloidal $\mathrm{Au}$-WGA labelling was specific to the cell walls and was localized predominantly in the inner wall layers 4-6 (Fig. 2b). At the dome-shaped bud scar (Fig. 2c), layers 2, 3 and 4 were not apparent and the primary septum (Shannon \& Rothman, 1971; Cabib, 1975) appeared as an electron-transparent hemispherical rim directly beneath the outermost fibrillo-granular layer 1 . The heaviest intensity of $\mathrm{Au}-\mathrm{WGA}$ labelling occurred at the bud scar in close proximity to the boundary of layer 1 (Fig. $2 d$ ). A similar electron-transparent area was found in the median of mycelial cell junctions (Fig. $2 e$ ) where the outer electron-dense layers of the lateral walls were conspicuously absent. Au-WGA labelling was most dense at the mycelial septa (Fig. $2 f$ ), analogous to the heavy labelling of septa in budding yeasts.

The specificity of the $\mathrm{Au}-\mathrm{WGA}$ label for the cell wall was demonstrated on cells processed by two different fixation procedures. In cells fixed with $\mathrm{KMnO}_{4}$ (Fig. $3 a$ ) and G-O-T-O-U (Fig. $3 b$ ) labelling was confined to the wall and concentrated most heavily at the bud scar (Fig. $3 a$ ) and mother-bud septum (Fig. 3b). Colloidal gold without WGA (Fig. 3c) and Au-WGA-chitin aggregates (Fig. $3 d$ ) did not bind specifically to the wall of thin-sectioned cells.

\section{Effects of polyoxin $\mathrm{D}$ on $\mathrm{Au}-\mathrm{WG}$ A labelling}

Budding yeasts showed $\mathrm{Au}-\mathrm{WGA}$ labelling in walls of both the mother cell and bud with more extensive labelling in the thicker walls of the mother cells (Fig. $4 a$ ). Labelling was totally absent from the walls of incipient buds in yeasts treated for $4.5 \mathrm{~h}$ in polyoxin $\mathrm{D}$ (Fig. $4 b$ ). Although the walls of the bud were less thick than those of the mother cell, there were no discernible differences in number or arrangement of layers in the walls of the bud after drug treatment. Similarly, Au-WGA labelling was found in both mother cell and germ tube walls of control cultures (Figs $4 c$ and $5 a$ ) but not in polyoxin D-treated germ tubes (Figs $4 d$ and $5 b$ ). The latter also lacked true septa, which usually formed 1-2 $\mu \mathrm{m}$ distal to the mother cell-mycelial junction in control cultures (Figs $4 c$ and $5 a$ ). At this same relative position in drug-treated mycelia, the following morphological alterations were observed. (a) Cell walls often expanded to form the bulbous cells (Fig. $4 d$ ) that were evident by fluorescence light microscopy (Figs $1 e$ and $1 f$ ). The apparent lack of a bulbous projection in Fig. $5 b$ is an artifact of the plane of sectioning, since light microscopy invariably reveals bulbous cells. (b) The cytoplasm in this region often exhibited slight invaginations (Fig. $4 d$ ) or evaginations (Fig. 5b). (c) The Au-WGA labelling evident in the mother cell ended abruptly (Fig. $5 b$ ) or was present as an isolated cluster in an unlabelled segment of the germ tube wall (Fig. $4 d$ ). $(d)$ The lateral walls showed discontinuities and projections similar in appearance to the protruding rims of bud scar annuli (Fig. $5 b)$. (e) The cytoplasm in this vicinity contained numerous small vesicles and membranous profiles (Fig. $5 b$ ).

\section{DISCUSSION}

Wheat germ agglutinin, a plant lectin that binds to $\beta$-(1 $\rightarrow 4)-N$-acetyl-D-glucosamine units (Goldstein et al., 1975), complexed to colloidal gold was used as an indirect marker for chitin 
(Horisberger \& Vonlanthen, 1977; Roberts et al., 1983) on thin-sectioned cell walls. Chitin was visualized previously in yeast walls by using WGA complexed to chitobiosyl ferritin (Tronchin et al., 1981) and to colloidal gold (Horisberger \& Vonlanthen, 1977; Molano et al., 1980; Roberts et al., 1983). In accordance with these findings, we observed that $\mathrm{Au}-\mathrm{WGA}$ labelling was specific for $C$. albicans walls and was localized primarily in the inner electron-transparent wall layers and most densely in the septa of buds and mycelia. Chitin is known to be a major component of fungal septa (e.g. Cabib \& Bowers, 1971; Horisberger \& Vonlanthen, 1977; Molano et al., 1980; Tronchin et al., 1981; Gow \& Gooday, 1983; Gooday \& Gow, 1983). It had been suggested that the electron-transparent primary septum (Shannon \& Rothman, 1971) of yeasts and filamentous fungi corresponds to a single chitin-rich plate (Cabib \& Bowers, 1971; Cabib et al., 1974; Hunsley \& Gooday, 1974), bounded at both sides by a glucan-chitin layer (secondary septum) that is continuous with the inner layers of the peripheral wall (Kreger-Van Rij \& Veenhuis, 1971). Although we did observe that the Au-WGA labelling of the inner wall layers extended into the septum, we did not observe preferential labelling of the electrontransparent area in the septum; therefore, our data are more consistent with the recent model for the hyphal septum of C. albicans proposed by Gooday \& Gow (1983). In this model, the septum is composed of two juxtaposed chitin-rich plates continuous with the innermost layers of the lateral wall and separated by an electron-transparent area of unknown composition.

The fact that Au-WGA preferentially labelled the inner wall layers supported the concept of coaxial stratification of wall components in fungi. The ultrastructural images of the cell walls of Candida have revealed a multilayered arrangement (Farkaš, 1979; Wessels \& Sietsma, 1981), although the number of layers may vary with fixation procedure and thus range from 5 to 8 layers (Djaczenko \& Cassone, 1971; Cassone et al., 1973; Persi \& Burnham, 1981; Poulain et al., 1978, 1981). Interpretation of this stratification is difficult due to artifacts inherent in electron microscopic methods (Wessels \& Sietsma, 1981) and because contrast differences resulting from selective retention of electron-dense stains may not reflect actual chemical differences in the layers (Garrison, 1981). However, since chitin occurs in association with glucan and mannan polymers and protein in C. albicans walls (Chattaway et al., 1968), it might be anticipated that these components are distributed in the layers visible by electron microscopy. To probe the association between ultrastructural appearance and chemical composition, Candida walls have been cytochemically stained (Venezia \& Lachapelle, 1973; Horisberger \& Vonlanthen, 1977; Poulain et al., 1978, 1981; Tronchin et al., 1981) and wall components selectively extracted and enzymically hydrolysed (Chattaway et al., 1976; Cassone et al., 1978; Gow \& Gooday, 1983; Gooday \& Gow, 1983; Evron \& Drewe, 1984), and the data have been integrated into a hypothetical model for Candida wall architecture. In this model, amorphous antigenic mannans and mannoproteins comprise the outer electron-dense layers and inner wall matrices, while the inner electron-transparent layers contain the crystalline skeletal polysaccharides glucan and chitin responsible for mechanical strength (Farkaš, 1979). In corroboration of this model, we found $\mathrm{Au}-\mathrm{WGA}$ labelling for chitin localized predominantly in the inner electron-transparent wall layers.

That chitin is a major contributor to wall stability is shown by our results with polyoxin $\mathrm{D}$, an inhibitor of chitin synthase (Endo et al., 1970; Ohta et al., 1970). Earlier studies had shown that treatment of fungi with polyoxin D led to swelling of fungal cell walls or to lysis (Endo et al., 1970; Bowers et al., 1974; Cabib \& Bowers, 1975; Hector \& Pappagianis, 1983; Becker et al., 1983). This loss of structural integrity was thought to be due to the absence of chitin, which prevented septum formation and led to a weakening of the walls. The results in the present study confirmed that, in the presence of polyoxin D, septa did not form and chitin was not incorporated into the walls of $C$. albicans. Although septa were not formed either in buds or in mycelia, wall growth itself was not inhibited and ultrastructural appearance of the walls was not altered by the antibiotic. Budding continued but chains of cells failed to separate, and germ tubes grew as a series of swollen segments unseparated by true septa. The presumptive septal area in treated germ tubes was marked by cytoplasmic and lateral wall alterations and accumulation of vesicles, but primary septum formation was inhibited by the absence of chitin. These results confirmed that although chitin is not necessary for wall formation, it is an essential component for normal morphogenesis, maintenance of structural integrity and formation of primary septa. 
This work was supported by grants from the National Institutes of Allergy and Infectious Disease (AI-14387 and AI-42651). The editorial assistance of John Tullock is gratefully appreciated.

\section{REFERENCES}

BACON, J. S. D. (1981). Nature and disposition of polysaccharides within the cell envelope. In Yeast Cell Envelopes: Biochemistry, Biophysics, and Ultrastructure, vol. I, pp. 65-84. Edited by W. N. Arnold. Boca Raton, Florida: CRC Press.

Becker, J. M., Covert, N. L., Shenbagamurthi, P., Steinfeld, A. S. \& NaIder, F. (1983). Polyoxin D inhibits growth of zoopathogenic fungi. Antimicrobial Agents and Chemotherapy 23, 926-929.

BODEY, G. P. \& FAINSTEIN, V. (1985). Candidiasis. New York: Raven Press.

Bowers, B., LeVIN, G. \& CABIB, E. (1974). Effect of polyoxin $\mathrm{D}$ on chitin synthesis and septum formation in Saccharomyces cerevisiae. Journal of Bacteriology 119, 564-575.

CABIB, E. (1975). Molecular aspects of yeast morphogenesis. Annual Review of Microbiology 29, 191-214.

CABIB, E. \& Bowers, B. (1971). Chitin and yeast budding. Localization of chitin in yeast bud scars. Journal of Biological Chemistry 246, 152-159.

CABIB, E. \& BowERS, B. (1975). Timing and function of chitin synthesis in yeast. Journal of Bacteriology 124, 1586-1593.

Cabib, E., Ulane, R. \& Bowers, B. (1974). A molecular model for morphogenesis: the primary septum of yeast. Current Topics in Cellular Regulation 8, 1-32.

Cassone, A., Simonetti, N. \& Strippoli, V. (1973). Ultrastructural changes in the wall during germ-tube formation from blastospores of Candida albicans. Journàl of General Microbiology 77, 417-426.

Cassone, A., Mattia, E. \& Boldrini, L. (1978). Agglutination of blastospores of Candida albicans by Concanavalin $\mathrm{A}$ and its relationship with the distribution of mannan polymers and the ultrastructure of the cell wall. Journal of General Microbiology 105, 263-273.

Chattaway, F. W., Holmes, M. R. \& Barlow, A. J. E. (1968). Cell wall composition of the mycelial and blastospore forms of Candida albicans. Journal of General Microbiology 51, 367-376.

Chattaway, F. W., Shenolikar, S., O’Reilly, J. \& BARLOW, A. J. E. (1976). Changes in the cell surface of the dimorphic forms of Candida albicans by treatment with hydrolytic enzymes. Journal of General Microbiology 95, 335-347.

Duaczenko, W. \& CAssone, A. (1971). Visualization of new ultrastructural components in the cell wall of Candida albicans with fixatives containing TAPO. Journal of Cell Biology 52, 186-190.

Endo, A., KaKIKI, K. \& Misato, T. (1970). Mechanism of action of the antifungal agent polyoxin $\mathrm{D}$. Journal of Bacteriology 104, 189-196.

EVRON, R. \& DREWE, J. A. (1984). Demonstration of the polysaccharides in the cell wall of Candida albicans blastospores, using silver methenamine staining and a sequence of extraction procedures. Mycopathologia 84, 141-149.

FARKAš, V. (1979). Biosynthesis of cell walls of fungi. Microbiological Reviews 43, 117-144.
Frens, G. (1973). Controlled nucleation for the regulation of the particle size in monodisperse gold suspensions. Nature Physical Sciences 241, 20-22.

GARRISON, R. G. (1981). Vegetative ultrastructure. In Yeast Cell Envelopes: Biochemistry, Biophysics and Ultrastructure, vol. II, pp. 139-160. Edited by W. N. Arnold. Boca Raton, Florida: CRC Press.

Goldstein, I. J., Hammarström, S. \& Sundblad, G. (1975). Precipitation and carbohydrate-binding specificity studies on wheat germ agglutinin. Biochimica et biophysica acta 405, 53-61.

Gooday, G. W. \& Gow, N. A. R. (1983). A model of the hyphal septum of Candida albicans. Experimental Mycology 7, 370-373.

Gow, N. A. R. \& Gooday, G. W. (1983). Ultrastructure of chitin in hyphae of Candida albicans and other dimorphic and mycelial fungi. Protoplasma 115, 5258.

Hayashibe, M. \& Katohda, S. (1973). Initiation of budding and chitin-ring. Journal of General and Applied Microbiology 19, 23-39.

HeCTOR, R. F. \& PAPPAGIANIS, D. (1983). Inhibition of chitin synthesis in the cell wall of Coccidioides immitis by polyoxin D. Journal of Bacteriology 154, 488-498.

HoRI, M., Kakiki, K., Suzuki, S. \& Misato, T. (1971). Studies on the mode of action of polyoxins. Part III. Relation of polyoxin structure to chitin synthetase inhibition. Agricultural and Biological Chemistry 35, 1280-1291.

HoRISBERGER, M. \& VonlantheN, M. (1977). Location of mannan and chitin on thin sections of budding yeasts with gold markers. Archives of Microbiology 115, 1-7.

Hunsley, D. \& GoOday, G. W. (1974). The structure and development of septa in Neurospora crassa. Protoplasma 82, 125-146.

Isono, K., Nagatsu, J., Kobinata, K., Sasaki, K. \& SuzUKI, S. (1967). Studies on polyoxins, antifungal antibiotics. Part V. Isolation and characterization of polyoxins C, D, E, F, G, H, and I. Agricultural and Biological Chemistry 31, 190-199.

KREGER-VAN RIJ, N. J. W. \& Veenhuis, M. (1971). A comparative study of the cell wall structure of basidiomycetous and related yeasts. Journal of General Microbiology 68, 87-95.

Lee, K. L., Buckley, H. R. \& CAmpbell, C. C. (1975). An amino acid liquid synthetic medium for the development of mycelial and yeast forms of Candida albicans. Sabouraudia 13, 148-153.

MAEDA, H. \& IsHIDA, N. (1967). Specificity of binding of hexopyranosyl polysaccharides with fluorescent brightener. Journal of Biochemistry 62, 276-278.

Meunier-Carpentier, F., Kiehn, T. E. \& ARMSTRONG, D. (1981). Fungemia in the immunocompromised host. Changing patterns, antigenemia, high mortality. American Journal of Medicine 71, 363-370.

Mitchell, L. H. \& Soll, D. R. (1979). Commitment to germ tube or bud formation during release from 
stationary phase in Candida albicans. Experimental Cell Research 120, 167-179.

Molano, J., Bowers, B. \& CABIB, E. (1980). Distribution of chitin in the yeast cell wall. An ultrastructural and chemical study. Journal of Cell Biology 85, 199212.

Muzzarelli, R. A. A. (1977). Chitin. Oxford: Pergamon Press.

Ohta, N., KaKiki, K. \& Misato, T. (1970). Studies on the mode of action of polyoxin D. Part II. Effect of polyoxin $D$ on the synthesis of fungal cell wall chitin. Agricultural and Biological Chemistry 34, 12241234.

Persi, M. A. \& Burnham, J. C. (1981). Use of tannic acid as a fixative-mordant to improve the ultrastructural appearance of Candida albicans blastospores. Sabouraudia 19, 1-8.

Poulain, D., Tronchin, G., Dubremetz, J. F. \& BigueT, J. (1978). Ultrastructure of the cell wall of Candida albicans blastospores: study of its constitutive layers by the use of a cytochemical technique revealing polysaccharides. Annales de Microbiologie (Institut Pasteur) 129A, 141-153.

Poulain, D., Tronchin, G., Jouvert, S., Herbaut, J. \& BigueT, J. (1981). Architecture pariétale des blastospores de Candida albicans: localisation de composants chimiques et antigéniques. Annales de Microbiologie (Institut Pasteur) 132A, 219-238.
Roberts, R. L., Bowers, B., Slater, M. L. \& Cabib, E. (1983). Chitin synthesis and localization in cell division cycle mutants of Saccharomyces cerevisiae. Molecular and Cellular Biology 3, 922-930.

Shannon, J. L. \& Rothman, A. H. (1971). Transverse septum formation in budding cells of the yeastlike fungus Candida albicans. Journal of Bacteriology 106, 1026-1028.

Shenbagamurthi, P., Smith, H. A., Becker, J. M. \& NAIDER, F. (1982). Purification of polyoxin D by reversed-phase high-performance liquid chromatography. Journal of Chromatography 245, 133-137.

SPURR, A. R. (1969). A low-viscosity epoxy resin embedding medium for electron microscopy. Journal of Ultrastructural Research 26, 31-43.

Tronchin, G., Poulain, D., Herbaut, J. \& Biguet, J. (1981). Localization of chitin in the cell wall of Candida albicans by means of wheat germ agglutinin. Fluorescence and ultrastructural studies. European Journal of Cell Biology 26, 121-128.

Venezia, R. A. \& Lachapelle, R. C. (1973). The use of ferritin-conjugated antibodies in the study of cell wall components of Candida albicans. Canadian Journal of Microbiology 19, 1445-1448.

Wessels, J. G. H. \& Sietsma, J. H. (1981). Fungal cell walls: a survey. In Plant Carbohydrates II: Extracellular Carbohydrates, pp. 352-394. Edited by W. Tanner \& F. A. Loewus. Berlin: Springer-Verlag. 